Kelola

Jurnal Manajemen Pendidikan

Magister Manajemen Pendidikan

ISSN 2443-0544

FKIP Universitas Kristen Satya Wacana

Volume: 3, No. 1, Januari-Juni 2016

jurnalkelola@gmail.com

Halaman: 49-66

\title{
EVALUASI PENYELENGGARAAN PROGRAM PENDIDIKAN INKLUSIF DI KOTA PALANGKA RAYA ${ }^{1}$
}

\author{
Dwi Sartica \\ Alumni Program Pascasarjana Magister Manajemen Pendidikan \\ FKIP-Universitas Kristen Satya Wacana \\ dwisartica02@yahoo.com; \\ Bambang Ismanto \\ Program Pascasarjana Magister Manajemen Pendidikan \\ FKIP-Universitas Kristen Satya Wacana \\ bambang.ismanto@staff.uksw.edu
}

\begin{abstract}
Inclusive education program (PI) is a product of the policies of the regional government held Education Department of Palangkaraya and must be implemented by all schools. The purpose of this study was to gather information for the evaluation of the implementation of programs in SD Negeri 6 Bukit Tunggal, SMP Negeri 3 and SMAN 4. The data was collected through interview and documentation study. Evaluation model used in this study is the CIPP. The subjects of this study were principal, regular teachers, and Guidance and Counceling Teachers of each school. The results of the evaluation context showed that the program has met the needs of PIs and parents of students with special needs; the population served were students with special needs and is still in the category of mild to moderate; as well as helpful programs so that school the full confidence of the public and an opportunity to increase the number of crew members who served. The results of the evaluation input indicated that the special facilities were inadequate; school involving all stakeholders in the school and some from outside; financing comes from use of the funds, scholarships, and / or budget; and the school does not have Special Guidance Teacher (SGT). The results of the evaluation process showed that new Education Department of Palangkaraya one to monitor and evaluate; teacher competence was good enough; learning in general but the treatment given on an individual basis, and extracurricular activities reserved for the crew; facilities not helpful enough; and the obstacles encountered was no SGT, facilities not adequate, specialized training has not been evenly distributed, no further monitoring of the relevant Department, and there is no standard for the evaluation system. The results of the product evaluation showed that the academic and non academic achievement of were students with special needs good enough. In addition, there were many number of crew members who served. The implication of this study is to provide recommendations for schools and related agencies for the improvement of the sustainability of the program.
\end{abstract}

Keywords: Inclusive education program, evaluation program, CIPP model

\footnotetext{
${ }^{1}$ Naskah ini sudah pernah dimuat dalam Prosiding Seminar Nasional Membangun Budaya Penelitian untuk Meningkatkan Kualitas Pendidikan Indonesia Dalam Perspektif Revolusi Mental Guru di Indonesia yang diselenggarakan oleh Progdi S2 MMP-FKIP-UKSW tanggal 12 Maret 2016
} 


\section{PENDAHULUAN}

Pendidikan khusus bagi anak berkebutuhan khusus (ABK) kini telah mengalami banyak perubahan dan perkembangan. Pada awalnya, pendidikan ABK bersifat terpisah dari masyarakat dan anak normal, yang mana pelaksanaannya berlangsung di sekolah luar biasa (SLB). SLB memiliki spesialisasi khusus sesuai dengan hambatan ABK dimana SLB-A diperuntukkan bagi anak dengan kelainan tunanetra, SLB-B diperuntukkan bagi anak dengan kelainan tunarungu, SLB-C diperuntukkan bagi anak dengan kelainan tunagrahita, dan SLB-D diperuntukkan bagi anak dengan kelainan tunadaksa. Keberadaan SLB ternyata tidak cukup mampu untuk mengakses pendidikan ABK secara merata dan optimal. Salah satu faktor yang menyebabkan kondisi demikian adalah jarak sekolah jauh dari rumah karena pada umumnya SLB terletak di ibukota provinsi dan sebagian di kabupaten/kota.

Menurut Permendiknas No. 70 Tahun 2009, pendidikan inklusif (PI) merupakan sistem penyelenggaraan pendidikan yang memberikan kesempatan kepada semua siswa yang memiliki kelainan dan potensi kecerdasan dan/atau bakat istimewa untuk mengikuti pendidikan atau pembelajaran dalam lingkungan pendidikan secara bersamasama dengan siswa normal pada umumnya. Dari peraturan ini, dalam pelaksanaannya PI bertujuan untuk memberikan kesempatan yang seluas-luasnya dan mewujudkan penyelenggaraan pendidikan yang menghargai keanekaragaman, dan tidak diskriminatif kepada semua peserta didik yang memiliki kelainan fisik, emosional, mental, dan sosial, atau memiliki potensi kecerdasan dan/atau bakat istimewa untuk memperoleh pendidikan yang bermutu sesuai dengan kebutuhan dan kemampuannya.

Kota Palangka Raya merupakan kota penyelenggara program PI. Label sebagai “Kota Pendidikan Inklusif” berlaku sejak tanggal pencanangannya yaitu 18 Oktober 2014 di kota Palangka Raya. Pencanangan ini merupakan kebijakan Disdikpora setempat yang diikuti dengan pembentukkan kelompok kerja (Pokja) PI Kota Palangka Raya. Pelaksanaan program PI diatur dalam Peraturan Walikota Palangka Raya Nomor 26 Tahun 2014 tentang Penyelenggaraan Pendidikan Khusus, Pendidikan Inklusif dan Pusat Sumber di Kota Palangka Raya. Data dari Dinas Pendidikan Kota Palangka Raya menunjukkan bahwa hingga tahun 2014 jumlah ABK di kota Palangka Raya adalah 895 anak, yang tersebar di lima wilayah kecamatan yaitu kecamatan Pahandut, Bukit Batu, Jekan Raya, Sabangau dan Rakumpit. 
Evaluasi Penyelengaraan Program Pendidikan Inklusif di Kota Palangkaraya | Dwi Sartica \& Bambang I.

Ada beberapa definisi tentang pendidikan inklusif. UNESCO (2009) menuliskan bahwa pendidikan inklusif adalah proses penguatan kapasitas sistem pendidikan untuk menjangkau semua siswa dan dengan demikian dapat dipahami sebagai strategi utama untuk mencapai Pendidikan Untuk Semua. Sementara itu, Salamanca Statement and Framework for Action on Special Needs Education pasal 2 (dalam Direktorat Pembinaan PKLK Pendidikan Dasar 2012) berbunyi bahwa "sekolah reguler dengan orientasi inklusif tersebut merupakan alat yang paling efektif untuk memerangi sikap diskriminasi, menciptakan masyarakat yang ramah, membangun masyarakat yang inklusif dan mencapai Pendidikan untuk Semua;...”. Dalam Deklarasi Bukittinggi (2005 dalam Direktorat Pembinaan PKLK Pendidikan Dasar 2012), pendidikan inklusif disebutkan sebagai "sebuah pendekatan terhadap peningkatan kualitas sekolah secara menyeluruh yang akan menjamin bahwa strategi nasional untuk PUS adalah benar-benar untuk semua". Berdasarkan ketiga definisi tersebut maka dapat ditarik kesimpulan bahwa pendidikan inklusi merupakan program layanan Pendidikan Untuk Semua (PUS), dimana siswa normal dan siswa berkebutuhan khusus dapat belajar bersama dalam satu kelas yang sama atau kelas reguler.

Pendidikan inklusif tidak hanya berkaitan dengan layanan PUS bagi ABK untuk belajar bersama siswa reguler di kelas umum. Lebih dari itu, pendidikan inklusif diberikan kepada ABK dengan jenis kebutuhan khusus atau kelainan yang bervariasi. Direktorat Pembinaan PKLK Dikdas (2012) menyebutkan bahwa pendidikan inklusif diberikan kepada "semua anak terlepas dari kemampuan ataupun ketidakmampuan mereka, jenis kelamin, status sosial-ekonomi, suku, latar belakang budaya atau bahasa dan agama menyatu dalam komunitas sekolah yang sama”. Sedangkan, salah satu landasan filosofis dari penerapan pendidikan inklusif menjelaskan bahwa pendidikan inklusif merupakan pelaksanaan pendidikan multikultural sehingga membantu peserta didik untuk bisa mengerti, menerima, dan menghargai sesama manusia yang berbeda suku, budaya, nilai, kepribadian, dan keberfungsian fisik atau psikologis. Sementara, Ahsan (2014) mendefinisikan, dalam terjemahan bahasa Indonesia, bahwa "pendidikan inklusif sekarang dianggap sebagai strategi yang layak untuk menciptakan pembelajaran lingkungan yang ramah untuk anak-anak/penyandang cacat, anak-anak dari etnis yang berbeda dan keragaman bahasa, anak-anak yang berasal dari latar belakang yang kurang beruntung secara sosial dan juga isu-isu gender". Dengan demikian, definisi ini memperkuat kedua definisi sebelumnya dimana pendidikan 
inklusif diberikan kepada siswa yang memiliki kasus atau hambatan yang bervariasi baik dari segi cacat fisik, etnografis, lingkungan/sosial budaya, latar belakang, maupun gender.

Penerapan pendidikan inklusif memberikan dampak yang baik bagi semua pihak, terkhususnya bagi ABK. Rallis \& Anderson (1994 dalam Devi \& Andrews 2007) mendefinisikan, dalam terjemahan bahasa Indonesia, bahwa "pendidikan inklusif adalah praktek yang menjamin bahwa setiap anak naik ke potensinya penuh sementara memvalidasi keunikan mereka”. Melalui pendidikan inklusif, dalam Deklarasi Bandung (2004 dalam Direktorat Pembinaan PKLK Pendidikan Dasar 2012), ABK mendapatkan kesempatan akses dalam segala aspek kehidupan sehingga menjadi generasi penerus yang handal, mendapatkan perlakuan yang manusiawi, mendapatkan pendidikan yang bermutu dan sesuai dengan potensi dan kebutuhan masyarakat serta mampu mengembangkan keunikan potensi secara optimal. Oleh karena itu, pendidikan inklusif dikatakan sebagai program pendidikan dalam rangka upaya mengembangkan kemampuan ABK dalam ranah kognitif, psikomotorik, soft skills, dan karakter. Dengan demikian, ABK akan hidup semakin bermakna setelah memperoleh pendidikan (Mudjito dkk. 2012).

Evaluasi berasal dari kata evaluation artinya nilai atau penilaian. Definisi dari Oxford AS, evaluasi adalah suatu upaya untuk menentukan nilai atau jumlah. Sedangkan menurut Suchman (1995 dalam Arikunto 2008), evaluasi adalah sebuah proses dalam menentukan hasil yang telah dicapai dalam beberapa kegiatan yang direncanakan untuk mendukung tercapainya tujuan. Lebih lanjut, Stufflebeam dan Shinkfield (2007) menjelaskan pengertian evaluasi adalah proses penggambaran, pencarian, dan pemberian informasi yang sangat bermanfaat bagi pengambil keputusan dalam menentukan alternatif keputusan. Dari ketiga definisi tersebut, evaluasi dapat disimpulkan sebagai upaya untuk menentukan hasil dari pelaksanaan suatu kegiatan dan pencapaian suatu tujuan, hingga pada akhirnya hasil tersebut dapat menjadi pertimbangan bagi suatu alternatif keputusan.

Sugiyo (2011) menyatakan bahwa "evaluasi program merupakan sebuah proses penilaian terhadap penyusunan program, pelaksanaan program, penilaian dan analisis hasil serta tindak lanjut kegiatan yang dilaksanakan”. Melalui evaluasi program, sejauh mana ketercapaian berjalannya suatu rangkaian program dapat dinilai 
Evaluasi Penyelengaraan Program Pendidikan Inklusif di Kota Palangkaraya | Dwi Sartica \& Bambang I.

dan tindak lanjut program dapat diputuskan oleh pembuat keputusan (Arikunto 2012). Menurut Arikunto (2012), tindak lanjut yang bisa diambil terhadap suatu keputusan kebijakan program terdiri dari empat macam. Pertama, program tetap dilanjutkan, dengan alasan bahwa program sangat bermanfaat. Kedua, program tetap dilanjutkan namun dengan penyempurnaan, dengan alasan bahwa dalam pelaksanaan program kurang baik/lancar. Ketiga, program dimodifikasi ulang, dengan alasan bahwa manfaat program kurang tinggi. Dan keempat, program dihentikan, dengan alasan bahwa berdasarkan data yang dikumpulkan ternyata hasil evaluasi tidak menunjukkan adanya manfaat dari program. Sementara itu, program dapat diartikan sebagai "rencana" atau dalam pengertian yang lebih praktis program adalah suatu unit atau satuan kegiatan. Dengan demikian, program merupakan sebuah sistem, yaitu rangkaian kegiatan yang dilakukan bukan hanya satu kali tetapi berkesinambungan. Dengan demikian, dari beberapa definisi 'evaluasi' dan 'program' maka evaluasi program adalah upaya menentukan hasil dari pelaksanaan serangkaian kegiatan sehingga pencapaian tujuan dari kegiatan tersebut dapat dinilai, hingga pada akhirnya hasil tersebut dapat menjadi pertimbangan bagi suatu alternatif keputusan bagi kegiatan selanjutnya.

Stufflebeam dan Shinkfield (2007) menjelaskan substansi dari evaluasi konteks adalah menilai kebutuhan, masalah, aset dan peluang, mengidentifikasi target populasi, dan mendiagnosa permasalahan dalam suatu lingkungan umum. Evaluasi masukan menilai pendekatan alternatif, rencana kerja, rencana kepegawaian, dan angggaran untuk kelayakan dan potensi efektivitas biaya untuk memenuhi kebutuhan sasaran dan mencapai tujuan. Evaluasi proses bertujuan untuk memberikan sebuah penilaian dalam implementasi kegiatan, serta memberikan umpan balik bagi kinerja staff. Evaluasi produk bertujuan untuk mengukur, menginterpretasikan dan menilai hasil pencapaian suatu program. Pendapat Stufflebeam memiliki kesamaan dengan pendapat Wirawan (2012). Substansi komponen CIPP dijelaskan bahwa evaluasi konteks berupaya mengidentifikasi kebutuhan yang mendasar pembuatan program; evaluasi input mengidentifikasi program, SDM, sarpras, pembiayaan, prosedur kerja, dan perencanaan; evaluasi proses menilai wujud program, pelaksana, waktu pelaksanaan dan anggaran; dan evaluasi produk menilai dampak program.

Evaluasi terhadap program PI membutuhkan jenis model yang cocok untuk melakukan kegiatan evaluasi tersebut. Model CIPP dianggap sesuai dengan kajian evaluasi penyelenggaraan program PI dengan beberapa pertimbangan. Pertama, model 
ini memiliki langkah-langkah yang jelas dalam pengungkapan setiap urutan program. Kedua, penulis dapat menganalisa secara detail mulai dari hal yang melatarbelakangi penyelenggaraan program (context), bentuk perencanaan program (input), pelaksanaan program (process) dan produk yang dihasilkan dari penyelenggaraan program (product). Ketiga, model ini sudah banyak dikenal dan diterapkan oleh para evaluator. Akhir dari evaluasi akan memberikan rekomendasi atas keberadaan program. Oleh karena itu, penyelenggaraan program pendidikan inklusif di kota Palangka Raya dievaluasi dengan menggunakan model CIPP.

\section{METODE PENELITIAN}

Penelitian ini merupakan penelitian evaluatif dengan menggunakan pendekatan kualitatif. Model evaluasi yang digunakan adalah model CIPP. Hasil evaluasi dalam penelitian ini dipaparkan dan digambarkan dalam bentuk kalimat, keterangan atau pernyataan bermakna terhadap penyelenggaraan program PI di kota Palangka Raya. Penelitian ini berlangsung di tiga sekolah terpilih sebagai penyelenggara program PI. Ketiga sekolah terpilih ini merupakan rekomendasi dari Dinas terkait. Ketiga sekolah tersebut dianggap cukup untuk mewakili semua sekolah penyelenggara PI dari seluruh jenjang pendidikan di kota Palangka Raya, untuk diteliti lebih lanjut. Subyek atau informan penelitian ini mencakup mencakup kepala sekolah, 1 guru kelas/mata pelajaran, dan 1 guru BP/BK. Dalam penelitian ini, data dikumpulkan dan diperoleh melalui teknik wawancara dan studi dokumentasi. Wawancara bersifat unstructured dimana wawancara terfokus pada suatu masalah tertentu (focused interview) dan bersifat bebas (free interview) dimana pertanyaan berpindah-pindah dari satu pokok ke pokok lain, sepanjang berkaitan dengan masalah yang diteliti. Wawancara dilakukan dengan kepala sekolah, guru kelas/mata pelajaran dan guru BP/BK dari tiap sekolah. Fokus pada tahap wawancara dengan kepala sekolah mencakup semua komponen yaitu context, input, process dan product dari penyelenggaraan program. Sedangkan wawancara dengan guru kelas/mata pelajaran dan guru BP/BK berfokus pada evaluasi input, process dan product. Selain data primer, data awal sebagai informasi tambahan diperoleh dari wawancara bersama Kasi. SLB Disdikpora. Sumber data lainnya yaitu data sekunder diperoleh melalui studi dokumentasi. Dalam studi dokumentasi, data fisik dari beberapa lokasi penelitian, yang sesuai dengan kebutuhan penulis atau tujuan penelitian, mencakup dokumen tertulis maupun foto. Dokumen tertulis yang diperoleh 
Evaluasi Penyelengaraan Program Pendidikan Inklusif di Kota Palangkaraya | Dwi Sartica \& Bambang I. dari Disdikpora mencakup panduan Grand Design, Perwali kota Palangka Raya No. 26 tahun 2014 dan SK penunjukkan sekolah piloting. Sementara, dokumen yang diperoleh dari sekolah meliputi profil sekolah, data $\mathrm{ABK}$, arsip surat tugas guru untuk mengikuti Diklat, program kerja APB komite sekolah, dan arsip surat monev sekolah penyelenggara PI. Sementara itu, dokumen foto yang diperoleh mencakup foto alat bantu ABK, pelaksanaan kegiatan workshop/lokakarya, kegiatan tes ABK untuk identifikasi/asesmen saat PPDB, keikutsertaan ABK dalam lomba-lomba dan OSN 2015, dan prestasi ABK.

Teknik analisis data pada penelitian ini menggunakan analisis data model interaktif dari Miles dan Huberman. Adapun tahapan dari analisis model ini bermulai dari koleksi data, reduksi data, penyajian data, hingga penarikan kesimpulan dan verifikasi. Dalam tahap koleksi data, penulis mengumpulkan seluruh data yang diperoleh baik dari kegiatan wawancara bersama subyek penelitian maupun data-data fisik dari studi dokumentasi. Kemudian, data dari hasil wawancara dan dokumentasi tersebut direduksi dan dipilah sesuai dengan kategori masing-masing. Dalam tahap ini, penulis mengambil data-data yang penting dan digolongkan sesuai dengan komponen CIPP. Setelah data sudah sesuai dengan komponen CIPP, penulis menyajikan dan menyusun data dalam bentuk gambar maupun tabel sehingga mudah dipahami. Berdasarkan data dan informasi yang diperoleh dan sudah diolah dan disajikan sebelumnya, maka penulis dapat menarik kesimpulan.

Dalam penelitian ini, penulis menguji validitas data dengan menggunakan teknik triangulasi data dan sumber. Teknik triangulasi data dilakukan penulis dengan cara membandingkan data hasil wawancara dengan data hasil studi dokumentasi. Sementara itu, teknik triangulasi sumber dilakukan penulis dengan cara membandingkan hasil wawancara oleh satu subyek dengan hasil wawancara oleh subyek lainnya. Dengan kedua teknik ini, tingkat kepercayaan dan keabsahan data dapat dipertanggungjawabkan.

\section{HASIL PENELITIAN DAN PEMBAHASAN}

\section{Evaluasi Context Penyelenggaraan Program Pendidikan Inklusif di Kota Palangka Raya}

Evaluasi context terhadap penyelenggaraan program pendidikan inklusif di kota Palangka Raya meliputi unsur penilaian terhadap kebutuhan yang belum terpenuhi, 
populasi yang dilayani, dan peluang atau manfaat dari penyelenggaraan program. Berdasarkan hasil penelitian di ketiga sekolah yang diteliti, penerimaan ABK sudah berlangsung sejak beberapa tahun sebelumnya yakni sebelum diberlakukannya kebijakan dari Disdikpora kota Palangka Raya yang mewajibkan semua sekolah melaksanakan program pendidikan inklusif. Alasan dari penerimaan ABK adalah karena ketiga sekolah tersebut melihat ada kebutuhan yang belum terpenuhi dimana para orang tua yang memiliki ABK menginginkan agar anaknya diterima di sekolah tersebut. Hasil temuan ini sesuai dengan hasil penelitian yang dilakukan oleh Isabella dkk. (2014) dimana implementasi pendidikan inklusi di SDN Negeri 131/IV Kota Jambi sangat dibutuhkan masyarakat sekitar karena adanya keinginan dan kebutuhan untuk menyekolahkan anaknya yang memiliki kebutuhan khusus di sekolah reguler. Oleh karena itu, ketiga sekolah yang diteliti dalam penelitian ini menerima dan melayani ABK meski kondisi pelayanan sekolah masih terbatas.

Selain pertimbangan atas kebutuhan yang belum terpenuhi, hasil temuan menunjukkan bahwa populasi yang dilayani adalah peserta didik dengan kebutuhan khusus dan berpotensi pada kecerdasan dan/atau bakat istimewa, yang direkrut dengan prioritas pada jarak terdekat domisili anak ke sekolah. Hasil temuan ini sesuai dengan Permendiknas No. 70 Tahun 2009 pasal 3 ayat 1 dimana peserta didik dengan kelainan fisik, emosional, mental, sosial atau memiliki potensi kecerdasan dan/atau bakat istimewa berhak mengikuti pendidikan inklusif pada satuan pendidikan tertentu sesuai dengan kebutuhan dan kemampuannya. Dengan penerimaan peserta didik berkebutuhan khusus, ketiga sekolah mendapat manfaat atas kepercayaan dan apresiasi yang diberikan oleh masyarakat khususnya orang tua $\mathrm{ABK}$ terhadap pelaksanaan program pendidikan inklusif. Temuan ini sejalan dengan pernyataan Mudjito dkk.. (2012) dimana anak-anak dengan kondisi dan kendala tertentu dan/atau tidak mendapatkan pelayanan pendidikan, sebaiknya memperoleh akses yang mudah dalam memperoleh pendidikan..

Berdasarkan hasil temuan dari semua aspek pada komponen context terhadap penyelenggaraan program PI di ketiga sekolah, secara tidak langsung agenda Pokja PI untuk masa 2014-2018 sudah berjalan dan sedang berlangsung. Hal ini terlihat pada agenda atau kalender tahunan Pokja PI untuk tahun 2014-2018 poin (d) tentang "pemerataan akses pendidikan atau pelayanan imklusif di setiap kecamatan dengan 
Evaluasi Penyelengaraan Program Pendidikan Inklusif di Kota Palangkaraya | Dwi Sartica \& Bambang I. membuat sekolah piloting dari jenjang TK, SD, SMP, SMA/SMK”. Pemerataan akses yang dimaksud adalah pemenuhan kebutuhan orang tua dan $\mathrm{ABK}$; semua $\mathrm{ABK}$ dengan jenis kebutuhan khusus kelas ringan hingga sedang terlayani; serta masyarakat atau sosial memberikan kepercayaan penuh kepada sekolah dalam melayani ABK.

\section{Evaluasi Input Penyelenggaraan Program Pendidikan Inklusif di Kota Palangka Raya.}

Evaluasi input terhadap penyelenggaraan program pendidikan inklusif di kota Palangka Raya meliputi unsur penilaian terhadap potensi sekolah, perencanaan program, anggaran, dan sumber daya manusia. Dalam pelaksanaan program, sarana prasarana sebagai pendukung program di ketiga sekolah yang diteliti memiliki ketersediaan yang bervariasi. Hasil penelitian di SDN 6 Bukit Tunggal dan SMPN 3 menunjukkan bahwa kedua sekolah ini masih mengandalkan sarana prasarana yang sudah dimiliki sebelumnya. Sarpras ini umumnya digunakan secara merata baik siswa reguler maupun ABK. Hal ini dianggap benar menurut Direktorat Pembinaan SLB (2007) dimana sarana dan prasarana umum yang dibutuhkan sekolah penyelenggara program pendidikan inklusif cenderung sama dengan sekolah reguler pada umumnya. Terkhusus pada alat bantu yang digunakan dan disesuaikan dengan kebutuhan ABK, SDN 6 Bukit Tunggal memiliki ketersediaan alat peraga yang masih terbatas. Selain itu, kedua sekolah belum didukung dengan prasarana yang memadai seperti ruang atau kelas khusus guna melayani ABK secara individual serta jalur khusus bagi ABK yang menggunakan kursi roda. Hal ini tidak sesuai dengan Perwali Palangka Raya No. 26 Tahun 2014 pasal 53 ayat 1 dimana "penyelenggara satuan pendidikan menyediakan sarana dan prasarana pendidikan yang memadai dan menjamin kelancaran program pendidikan”. Sehubungan dengan acuan yang sama, secara khusus pada ayat 2 menambahkan bahwa "Pemerintah, Pemerintah Daerah, dan masyarakat memfasilitasi sarana dan prasarana pendidikan yang disesuaikan dengan kondisi setempat”.

Sementara itu, SMAN 4 yang memanfaatkan sarpras yang sudah ada di sekolah, juga mendapatkan bantuan sarana yang memadai berupa alat bantu seperti kursi roda, kaca mata, laptop, dan tongkat penyangga/jalan. Bantuan tersebut diberikan oleh pemerintah pusat dan PK-PLK pada tahun 2012 dimana pemberian ini disesuaikan dengan keberadaan dan jenis kebutuhan/kelainan ABK. Hasil temuan ini sudah sesuai 
dengan Perwali Palangka Raya No. 26 Tahun 2014 pasal 53 ayat 1 dan 2 serta Permendiknas No. 70 Tahun 2009 pasal 11 ayat 1, 2, dan 4c.

Terkait temuan dalam ketersediaan sarpras di ketiga sekolah, secara tidak langsung agenda Pokja PI poin (e) periode tahun 2014-2018 belum berjalan secara menyeluruh atau merata. Agenda ini berisi pengadaan sarana dan prasarana sekolah piloting maupun yang telah menyelenggarakan pendidikan inklusif. Belum berjalannya agenda ini secara menyeluruh atau merata dikarenakan Pokja PI masih sedang mengupayakan pengadaan sarpras.

Terkait dengan jenis kebutuhan yang dimiliki siswa, ketiga sekolah memiliki ABK dengan jenis kebutuhan khusus bervariasi dan masuk dalam kategori ringan hingga cukup. Berdasarkan hasil penelitian, ketiga sekolah tersebut memiliki ABK dengan kebutuhan khusus lamban belajar atau slow learner dengan jumlah siswa cukup banyak dibanding dengan jenis kebutuhan khusus lainnya. Sebagian sekolah juga memiliki siswa dengan kebutuhan khusus tuna daksa, tuna rungu ringan, hiperaktif, autis, dan low vision. Temuan ini sama dengan hasil temuan Nono (2013) dimana jenis kebutuhan khusus ABK di sekolah dasar di Kabupaten Pontianak cukup beragam dan didominasi 78,75\% siswa dengan kelainan lamban belajar (slow learner). Sementara itu, temuan peneliti menunjukkan bahwa sekolah memiliki total ABK yang bervariasi dimana SDN 6 Bukit Tunggal memiliki 43 siswa, SMPN 3 memiliki 12 siswa, dan SMAN 4 memiliki 15 siswa. Dengan demikian, hasil temuan juga sesuai dengan Permendiknas No. 70 Tahun 2009 pasal 3 ayat 2 dimana jenis kelainan ABK sangat bervariasi. Dalam hal ini, sekolah memiliki variasi jumlah ABK yang disertai dengan jenis kebutuhan khusus yang berbeda-beda pula.

Di sisi lain, pelaksanaan program pendidikan inklusif melibatkan pihak di dalam maupun di luar sekolah. Hasil penelitian menunjukkan bahwa ketiga sekolah yang diteliti melibatkan pihak dalam sekolah yang meliputi kepala sekolah, komite, pengawas sekolah, wakasek, guru kelas/mapel, wali kelas dan/atau guru BK. Hasil temuan ini dibenarkan Direktorat Pembinaan PKLK Pendidikan Dasar (2012) bahwa salah satu prinsip penyelenggaraan pendidikan inklusif adalah prinsip keterlibatan, dimana penyelenggaraan pendidikan inklusif harus melibatkan seluruh komponen pendidikan terkait. Sementara, keterlibatan dari pihak luar sekolah berupa bantuan dan kerja sama dengan pihak terkait hanya diperoleh oleh satu sekolah saja yaitu SMAN 4. 
Evaluasi Penyelengaraan Program Pendidikan Inklusif di Kota Palangkaraya | Dwi Sartica \& Bambang I.

Sekolah ini bekerja sama dengan PK-PLK dan psikolog, terkhusus dalam proses PPDB. Temuan ini sudah sesuai dengan Direktorat Pembinaan PKLK Pendidikan Dasar Tahun 2012 dan Permendiknas No. 70 Tahun 2009 pasal 11 ayat 1-5. Sedangkan, SDN 6 Bukit Tunggal dan SMPN 3 belum pernah bekerja sama atau melibatkan pihak luar seperti psikolog, tenaga ahli, atau pihak tertentu.

Sumber dana dalam pelaksanaan program pendidikan inklusif diperoleh atau dimanfaatkan ketiga sekolah yang diteliti baik dari dana BOS, dukungan APBD, ataupun bantuan beasiswa. Berdasarkan hasil penelitian, SDN 6 Bukit Tunggal dan SMPN 3 mensiasati pemenuhan kebutuhan ABK melalui dana BOS, meskipun SMPN 3 pernah mendapat bantuan beasiswa ABK-PKLK. Sementara SMAN 4 mendapat dukungan dana dari APBD akan tetapi sekolah ini belum pernah mendapat bantuan dana khusus. Hasil temuan ini dinilai sudah sesuai dengan kriteria penyelenggaraan pendidikan inklusif yang tertuang dalam Perwali No. 26 Tahun 2014 pasal 55 ayat 1 yang menjelaskan bahwa "sumber pendanaan penyelenggaraan program ini diperoleh dari APBN Pemerintah, APBD Pemerintah Provinsi, APBD Pemerintah Kota, masyarakat, dan/atau sumber lain yang sah dan tidak mengikat". Dengan demikian, sekolah boleh menggunakan dana BOS di samping penyaluran dana dari APBD dan beasiswa khusus untuk ABK.

Sementara dalam hal sumber daya manusia (SDM) yaitu guru pendamping khusus (GPK), ketiga sekolah yang diteliti belum memiliki GPK yang berlatar belakang pendidikan khusus atau pendidikan luar biasa. Fakta ini tidak sesuai dengan Permendiknas No. 70 tahun 2009 pasal 10 ayat 1 yang menetukan bahwa "pemerintah kabupaten/kota wajib menyediakan paling sedikit satu orang GPK pada satuan pendidikan yang ditunjuk untuk menyelenggarakan pendidikan inklusif". Terkait temuan ini, penanganan ABK di ketiga sekolah ini langsung ditangani oleh guru kelas/mapel, wali kelas dan guru BK. Namun dalam hal pendampingan dan penanganan secara khusus dan intensif di SMPN 3 dan SMAN 4, ABK ditangani langsung oleh guru BK yang pernah mengikuti diklat cara menangani ABK, sementara ABK di SDN 6 Bukit Tunggal hanya ditangani oleh wali kelas dan guru kelas. Guru-guru dalam situasi tersebut dianggap sebagai "GPK" versi sekolah masing-masing.

Sebagian guru kelas/mapel, wali kelas dan guru BK di ketiga sekolah yang diteliti ini pernah mendapatkan workshop, diklat, sosialisasi dan/atau pelatihan khusus 
untuk meningkatkan kompetensi. Temuan ini sesuai dengan Permendiknas Nomor 70 Tahun 2009 pasal 10 ayat 3, 5, dan 6 yang menjelaskan bahwa "pemerintah kabupaten/kota wajib meningkatkan kompetensi di bidang pendidikan khusus bagi tenaga pendidik dan tenaga kependidikan pada satuan pendidikan penyelenggara pendidikan inklusif", "pemerintah dan pemerintah provinsi membantu meningkatkan kompetensi di bidang pendidikan khusus bagi tenaga pendidik dan tenaga kependidikan pada satuan pendidikan penyelenggara pendidikan inklusif”, yang dapat dilakukan melalui "P4TK, LPMP, perguruan tinggi, lembaga pendidikan dan pelatihan lainnya di lingkungan pemerintah daerah, Departemen Pendidikan Nasional dan/atau Departemen Agama, KKG/KKKS, KKPS, MGMP, MKS, MPS, dan sejenisnya.

\section{Evaluasi Process Penyelenggaraan Program Pendidikan Inklusif di Kota Palangka Raya.}

Sejak pencanangan Kota Pendidikan Inklusif pada 18 Nopember 2014 lalu, Disdikpora baru pertama kali memonitor pelaksanaan program pendidikan inklusif melalui surat permohonan yang diberikan kepada semua sekolah perihal monitoring dan evaluasi sekolah penyelenggara pendidikan inklusif. Surat ini ditujukan agar masing-masing sekolah segera mengidentifikasi tiap peserta didik yang memiliki kebutuhan khusus/kelainan, melakukan pendataan sesuai format yang diminta dan segera melaporkan ke Disdikpora untuk segera ditindaklanjuti. Hasil temuan menunjukkan bahwa ketiga sekolah yang diteliti mendapat surat pemberitahuan ini dan langsung menindaklanjuti. Temuan ini sesuai dengan Perwali Palangka Raya No. 26 Tahun 2014 pasal 56 ayat 1 dan 2 dimana pengawasan sekolah yang meliputi pemantauan, supervisi, evaluasi, pelaporan, dan tindak lanjut hasil pengawasan, dilakukan oleh pendidik, kepala sekolah, kelompok kerja atau satuan tugas pada sekolah sesuai dengan kewenangan masing-masing dan pengawas TK/SD/SMP/SMA serta dapat berkoordinasi dengan pengawas sekolah PLB. Dalam hal ini, Disdikpora sudah melakukan pengawasan satu kali kepada sekolah penyelenggara pendidikan inklusif yang kemudian mendapat hasil atau respon dari sekolah untuk kemudian ditindaklanjuti.

Dalam proses pembelajaran di dalam kelas, hasil temuan menunjukkan bahwa guru di ketiga sekolah yang diteliti memiliki kompetensi yang cukup memadai. Hal ini terbukti dari penyusunan RPP, pemberian materi dan bahan ajar kepada ABK dengan 
Evaluasi Penyelengaraan Program Pendidikan Inklusif di Kota Palangkaraya | Dwi Sartica \& Bambang I.

menggunakan kurikulum dan materi/bahan ajar yang sama atau reguler. Guru tidak memberikan atau membedakan kurikulum dan materi/bahan ajar secara terstruktur. Selain itu, guru menggunakan RPP reguler yang diberikan secara merata kepada semua siswa. Menurut Direktorat Pembinaan PKLK Pendidikan Dasar (2012) kurikulum yang digunakan dalam penyelenggaraan pendidikan inklusif pada dasarnya adalah kurikulum standar nasional yang berlaku di sekolah umum. Akan tetapi karena ragam hambatan ABK sangat bervariasi, baik yang bersifat ringan hingga sedang, maka dalam implementasinya harus ada modifikasi kurikulum tingkat satuan pendidikan yang sesuai dengan standar nasional dan kebutuhan ABK. Hal ini diperkuat Permendiknas No. 70 Tahun 2009 pasal 7 yang menyebutkan bahwa kurikulum yang digunakan adalah kurikulum tingkat satuan pendidikan yang mengakomodasi kebutuhan dan kemampuan ABK sesuai bakat, minat dan potensinya. Terkait pada acuan itu, hasil penelitian menunjukkan bahwa sebagian sekolah melakukan modifikasi kurikulum melalui pemberian atau pelayanan tambahan jam belajar pada siang atau sore hari untuk kegiatan pengayaan, remedi, atau pembimbingan khusus di luar jam sekolah.

Dalam proses pembelajaran, temuan menunjukkan bahwa guru-guru di ketiga sekolah yang diteliti melayani dan memperlakukan ABK sama dengan siswa normal lainnya. Oleh karena itu, ABK juga menyesuaikan diri pada proses pembelajaran yang berlangsung di dalam kelas. Hasil temuan lain menunjukkan bahwa penggunaan kurikulum dan pemberian soal latihan tetap sama tapi penyesuaian dilakukan secara individu dalam hal evaluasi dan pelayanan lainnya. Bagi ABK yang slow learner, standar nilai dibedakan dan disesuaikan yaitu diturunkan dari standar KKM siswa normal pada umumnya. Kemudian, ABK akan mendapatkan pelayanan lebih apabila dianggap perlu untuk pengayaan, remedi dan sebagainya baik di saat jam istirahat maupun di luar jam sekolah. Hasil temuan ini sesuai menurut Direktorat Pembinaan PKLK Pendidikan Dasar (2012) tentang salah satu prinsip pembelajaran sekolah inklusif yaitu prinsip individual, dimana "guru perlu mengenal kemampuan awal dan karakteristik setiap anak secara mendalam, baik dari segi kemampuan maupun ketidakmampuannya dalam menyerap materi pelajaran, kecepatan maupun kelambatannya dalam belajar, dan perilakunya, sehingga setiap kegiatan pembelajaran masing-masing anak mendapat perhatian dan perlakuan yang sesuai”.

Berdasarkan hasil penelitian, selain proses belajar di kelas, ketiga sekolah yang diteliti juga menyiapkan dan membuka kegiatan ekstrakurikuler yang juga diberikan 
kepada ABK. Hasil temuan menunjukkan bahwa ABK diberi kebebasan untuk memilih kegiatan ekstrakurikuler yang tersedia sesuai bakat, minat, kemampuan dan ketertarikan ABK itu sendiri. Hal ini tentunya ditujukan tidak untuk merugikan atau menyusahkan $\mathrm{ABK}$, melainkan untuk mendukung kemampuan $\mathrm{ABK}$ di bidang non akademik. Temuan ini sesuai dan dibenarkan berdasarkan Perwali Palangka Raya No. 26 Tahun 2014 pasal 47 ayat 2 dimana peserta didik memiliki hak untuk "memperoleh layanan pendidikan sesuai dengan bakat, minat, kemampuan, kecerdasan, dan kebutuhan khususnya. Dalam hal ini, kegiatan ekstrakurikuler merupakan salah satu bentuk layanan pendidikan yang diberikan dan disediakan sekolah bagi semua siswa.

Dari pelaksanaan program pendidikan inklusif baik sebelum maupun sesudah pencanangan sebagai Kota Pendidikan Inklusif, ketiga sekolah menghadapi beberapa kendala. Kendala yang ditemukan di SDN 6 Bukit Tunggal adalah tidak tersedianya GPK, sarpras belum memadai, dan pelatihan khusus bagi guru tidak ada. Temuan ini tidak sesuai dengan Permendiknas No. 70 Tahun 2009 pasal 6 ayat 1, 2, dan 3 dimana pemerintah kabupaten/kota menjamin terselenggaranya pendidikan inklusif sesuai dengan kebutuhan ABK dan menjamin tersedianya sumberdaya pendidikan inklusif, serta pemerintah dan pemerintah provinsi membantu tersedianya sumber daya pendidikan inklusif.

Kendala yang ditemukan di SMPN 3 serupa dengan yang ditemui di SDN 6 Bukit Tunggal, hanya berbeda dalam hal pelatihan khusus bagi guru yang belum merata. Temuan ini belum sesuai dengan Permendiknas No. 70 tahun 2009 pasal 10 ayat 3, 5, dan 6. Selain itu, SMPN 3 mengalami kendala dalam menggunakan atau mengarahkan penggunaan kursi roda yang sudah diberikan Dinas terkait namun belum ada monitoring langsung sehingga alat bantu belum bisa digunakan sebagaimana mestinya. Temuan ini tidak sesuai dengan Permendiknas No. 70 Tahun 2009 pasal 12 dimana "pemerintah, pemerintah provinsi dan pemerintah kabupaten/kota melakukan pembinaan dan pengawasan pendidikan inklusif sesuai dengan kewenangannya”.

Sementara itu, kendala yang ditemukan di SMAN 4 serupa dengan yang ditemukan di SDN 6 Bukit Tunggal dan SMPN 3 dimana GPK tidak tersedia dan prasarana masih terbatas. Kendala lainnya adalah sistem penilaian UN bagi ABK masih disamaratakan dengan siswa reguler dan tidak ada standar baku evaluasi bagi ABK. Hasil temuan menunjukkan bahwa sekolah masih menggunakan standar kelulusan bagi 
Evaluasi Penyelengaraan Program Pendidikan Inklusif di Kota Palangkaraya | Dwi Sartica \& Bambang I.

ABK yang sama dengan anak normal demi mengantisipasi dan menghindari adanya ketidaklulusan ABK. Dengan demikian, ABK diharapkan tetap bisa lulus dan bersaing dengan anak normal dalam UN meski pada umumnya standar kelulusan diberlakukan sama bagi seluruh siswa. Temuan ini tidak sesuai dengan Permendiknas No. 70 tahun 2009 pasal 9 ayat 2 dan 4 yang menjelaskan bahwa ABK yang mengikuti pembelajaran berdasarkan kurikulum sesuai dengan atau di atas standar nasional pendidikan wajib mengikuti ujian nasional. Dan apabila ABK tersebut menyelesaikan pendidikan dan lulus ujian sesuai dengan standar nasional pendidikan, ABK mendapatkan ijazah yang blankonya dikeluarkan oleh pemerintah. Sementara dalam ayat 3 dan 5 menjelaskan bahwa ABK yang mengikuti pembelajaran berdasarkan kurikulum di bawah standar nasional pendidikan wajib mengikuti ujian yang diselenggarakan sekolah. Dan apabila ABK menyelesaikan pendidikan berdasarkan kurikulum yang dikembangkan oleh sekolah di bawah standar nasional pendidikan, ABK mendapatkan surat tanda tamat belajar yang blankonya dikeluarkan oleh sekolah yang bersangkutan. Sementara, hasil temuan terhadap tidak adanya standar baku dalam hasil belajar ABK menyebabkan penilaian dilakukan guru secara subyektif. Temuan ini tidak sesuai dengan Permendiknas No. 70 tahun 2009 pasal 9 ayat 1, dimana "penilaian hasil belajar bagi peserta didik pendidikan inklusif mengacu pada kurikulum tingkat satuan pendidikan yang bersangkutan". Dengan demikian, kesimpulan dari kendala yang dihadapi ketiga sekolah yang diteliti meliputi ketidak-tersediaan GPK, keterbatasan sarpras, ketidak merataan pelatihan khusus bagi guru, belum ada monitoring lebih lanjut dari Dinas terkait, sistem penilaian UN yang masih disamaratakan, dan tidak adanya standar baku evaluasi hasil belajar ABK.

\section{Evaluasi Product Penyelenggaraan Program Pendidikan Inklusif di Kota Palangka Raya.}

Evaluasi product terhadap penyelenggaraan program pendidikan inklusif di kota Palangka Raya berupaya untuk melakukan penilaian terhadap dampak penyelenggaraan program terhadap perkembangan peserta didik. Perkembangan ABK baik dari segi akademik maupun non akademik disesuaikan dengan jenis kebutuhan khusus/kelainan ABK.

Di SDN 6 Bukit Tunggal para siswa ABK yang mayoritas slow learner mampu mencapai nilai standar sesuai KKM sehingga bisa naik kelas atau lulus. Sementara, 
perkembangan non akademik ABK cukup baik. ABK di SMPN 3 yang merupakan slow learner dan tuna daksa memiliki perkembangan akademik dan non akademik yang cukup baik atau rata-rata. Sedang ABK di SMAN 4 dengan jenis kebutuhan yang bervariasi memiliki perkembangan prestasi yang baik dan perkembangan non akademik yang baik bahkan membanggakan sekolah. Dengan demikian, maka dapat disimpulkan bahwa perkembangan atau prestasi ABK di ketiga sekolah secara garis besar cukup baik dan rata-rata. Hasil temuan ini sejalan dengan pendapat Mudjito dkk. (2012) yang menjelaskan bahwa setidaknya ada 4 ranah pendidikan yang harus diberikan dalam proses belajar mengajar yang mencakup ranah kognitif (pembentukan kemampuan ilmu atau daya nalar), psikomotorik (pembentukan bakat keterampilan), soft skills (pembentukan intrapersonality, interpersonality, karakter pribadi untuk dirinya, sosial dan dengan sang Pencipta), dan karakter (pembentukan hard skills dan soft skills).

\section{SIMPULAN DAN SARAN}

Berdasarkan hasil penelitian dan pembahasan di atas maka dapat ditarik beberapa kesimpulan.

1. Dari segi context, pelaksanaan program PI di Kota Palangka Raya dimaksudkan untuk memenuhi kebutuhan yang belum terpenuhi, yaitu permintaan orang tua ABK untuk menyekolahkan anak mereka di sekolah regular.

2. Dari segi input, pelaksanaan program PI di ketiga sekolah sudah menunjukkan bahwa ketersediaan sarpras umum sudah memenuhi kebutuhan semua siswa walau ketersediaan sarpras khusus bagi ABK belum memadai. Pelaksanaan program PI juga sudah cukup dibiayai baik dari alokasi dana BOS, beasiswa khusus, maupun APBD. Namun ketiga sekolah belum memiliki GPK sehingga ABK ditangani oleh guru umum/reguler.

3. Berdasarkan evaluasi terhadap komponen process, Dinas terkait baru pertama kali melakukan pengawasan melalui monitoring dan evaluasi ke sekolah. Kompetensi guru cukup memadai dalam menangani layanan individual bagi para ABK. Selain itu, terdapat kegiatan ekstrakurikuler yang diperuntukan bagi ABK. Masalah atau kendala yang ditemukan adalah tidak adanya GPK, sarpras khusus belum memadai, pelatihan khusus bagi guru di sebagian sekolah belum merata, belum ada monitoring lebih lanjut dari Dinas terkait, dan tidak ada standar baku dalam penilaian hasil belajar dan UN. 
Evaluasi Penyelengaraan Program Pendidikan Inklusif di Kota Palangkaraya | Dwi Sartica \& Bambang I.

4. Dari segi product, dampak pelaksanaan program terletak pada pencapaian prestasi ABK dan jumlah ABK yang terlayani. Perkembangan akademik (kognitif) dan non akademik (psikomotorik) ABK cukup baik. Sementara, jumlah ABK yang terlayani di ketiga sekolah tergolong variatif dan semua ABK dilayani sekolah dengan penyesuaian terhadap keadaan dan kemampuan sekolah.

Berdasarkan kesimpulan di atas, maka saran yang dapat diberikan dalam penyelenggaraan program pendidikan inklusif di kota Palangka Raya adalah:

1. Bagi sekolah penyelenggara program PI di kota Palangka Raya

a. guru dan/atau kepala sekolah yang sudah pernah mengikuti kegiatan diklat penanganan $\mathrm{ABK}$, pelatihan khusus dan sejenisnya, perlu saling berbagi pengalaman dengan guru yang belum pernah mengikuti kegiatan tersebut, baik dalam perencanaan, penanganan $\mathrm{ABK}$, maupun evaluasi.

b. Sekolah perlu melibatkan dan bekerja sama dengan orang tua ABK dalam hal penyampaian evaluasi, perkembangan atau pencapaian prestasi $\mathrm{ABK}$ baik di kelas maupun di luar kelas. Hal ini dapat dilakukan dengan parents' meeting, baik secara face-to-face ataupun lingkup besar di sekolah antara sekolah dengan orang tua, dengan waktu pelaksanaan yang disesuaikan berdasarkan kesepakatan bersama. Dengan demikian, orang tua bisa berkontribusi terhadap perkembangan anak ketika tidak dalam lingkup kegiatan belajar mengajar di sekolah.

2. Bagi Disdikpora kota Palangka Raya

Dinas perlu meninjau ulang dan mengevaluasi secara seksama apakah fakta atau hasil dari penyelenggaraan program pendidikan inklusif di sekolah-sekolah sudah sesuai dengan visi dan misi Pokja beserta program-program yang sudah direncanakan. Dengan demikian, Dinas/Pokja dapat membuat kebijakan perbaikan atau keputusan lebih lanjut.

\section{DAFTAR PUSTAKA}

Ahsan, M. T. 2014. "Inclusive Education: A Strategy to Address Diversity to Ensure Equal Right to Education. Editorial". Asian Journal of Inclusive Education (AJIE). Vo.2, No.1, April 2014, 1-3. Bangladesh: IEE, University of Dhaka.

Arikunto, Suharsimi. 2008. Evaluasi Program Pendidikan: Pedoman Teoritis Praktis bagi Mahasiswa dan Praktisi Pendidikan. Jakarta: Depdiknas. 
Devi, A. A., \& Andrews. 2007. "Inclusive Education in Guyana: Perspectives of Policy Makers, Teachers, and Parents of Children With Special Needs". Theses and Dissertations. Guyana: Ryenson University.

Direktorat Pembinaan PKLK Pendidikan Dasar. 2012. Permendiknas Nomor 70 Tahun 2009. Jakarta: Direktorat Jenderal Pendidikan Dasar Kementerian Pendidikan dan Kebudayaan.

Direktorat Pembinaan SLB. 2007. Pedoman Umum Penyelenggaraan Pendidikan Inklusif. Jakarta: Depdiknas. ,2012. Dasar-Dasar Evaluasi Pendidikan. Jakarta: Bumi Aksara.

Direktorat Pembinaan PKLK Pendidikan Dasar. 2012. Permendiknas Nomor 70 Tahun 2009. Jakarta: Direktorat Jenderal Pendidikan Dasar Kementerian Pendidikan dan Kebudayaan.

Isabella, dkk. 2014. "Evaluasi Penyelenggaraan Pendidikan Inklusif bagi Peserta Didik Berkebutuhan Khusus di SDN-131/IV Kota Jambi”. Jurnal TeknoPedagogi. Vo.4, No.2, September 2014, 45-59. Jambi: Universitas Jambi.

Mudjito, dkk. 2012. Pendidikan Inklusif. Editor: Wardi. Jakarta: Baduose Media.

Nono, G. Haryono. 2013. "Studi Evaluasi Program Pendidikan Inklusif Bagi ABK di Sekolah Dasar Kabupaten Pontianak". Jurnal Pendidikan dan Pembelajaran. Vo.2, No.1.

Peraturan Walikota Palangka Raya Nomor 26 Tahun 2014 Tentang Penyelenggaraan Pendidikan Khusus, Pendidikan Inklusif dan Pusat Sumber di Kota Palangka Raya.

Permendiknas Nomor 70 Tahun 2009 Tentang Pendidikan Inklusif Bagi Peserta Didik yang Memiliki Kelainan dan Memiliki Potensi Kecerdasan dan/atau Bakat Istimewa.

Stufflebeam. L. Daniel, Shinkfield, J. Anthony. 2007. Evaluation Theory, Models \& Applications. San Francisco: Jossey Bass.

Sugiyo. 2011. Bimbingan dan Konseling di Sekolah. Semarang: Widya Karya.

UNESCO. 2009. Policy Guidelenes on Inclusion in Education. France: UNESCO

Wirawan. 2012. Evaluasi: Teori, Model, Standar, Aplikasi, dan Profesi. Jakarta: Rajawali Pers. 